\title{
U-Pb age of the Diana Complex and Adirondack granulite petrogenesis
}

\author{
Asish R Basu ${ }^{1}$ and Wayne R Premo ${ }^{2}$ \\ ${ }^{1}$ Department of Earth and Environmental Sciences, University of Rochester, Rochester, \\ New York 14627, USA \\ ${ }^{2}$ U.S. Geological Survey, MS 963, Federal Center, Denver, CO 80225, USA
}

$\mathrm{U}-\mathrm{Pb}$ isotopic analyses of eight single and multi-grain zircon fractions separated from a syenite of the Diana Complex of the Adirondack Mountains do not define a single linear array, but a scatter along a chord that intersects the Concordia curve at $1145 \pm 29$ and $285 \pm 204$ Ma. For the most concordant analyses, the ${ }^{207} \mathrm{~Pb} /{ }^{206} \mathrm{~Pb}$ ages range between 1115 and $1150 \mathrm{Ma}$. Detailed petrographic studies revealed that most grains contained at least two phases of zircon growth, either primary magmatic cores enclosed by variable thickness of metamorphic overgrowths or magmatic portions enclosing presumably older xenocrystic zircon cores. The magmatic portions are characterized by typical dipyramidal prismatic zoning and numerous black inclusions that make them quite distinct from adjacent overgrowths or cores when observed in polarizing light microscopy and in backscattered electron micrographs. Careful handpicking and analysis of the "best" magmatic grains, devoid of visible overgrowth of core material, produced two nearly concordant points that along with two of the multi-grain analyses yielded an upper-intercept age of $1118 \pm 2.8 \mathrm{Ma}$ and a lowerintercept age of $251 \pm 13 \mathrm{Ma}$. The older age is interpreted as the crystallization age of the syenite and the younger one is consistent with late stage uplift of the Appalachian region. The $1118 \mathrm{Ma}$ age for the Diana Complex, some 35 Ma younger than previously believed, is now approximately synchronous with the main Adirondack anorthosite intrusion, implying a cogenetic relationship among the various meta-igneous rocks of the Adirondacks. The retention of a high-temperature contact metamorphic aureole around Diana convincingly places the timing of Adirondack regional metamorphism as early as $1118 \mathrm{Ma}$. This result also implies that the sources of anomalous hightemperature during granulite metamorphism are the syn-metamorphic intrusions, such as the Diana Complex.

\section{Introduction}

As granulites are generally believed to constitute a major portion of the lower continental crust, a better understanding of granulite petrogenesis can be expected to aid in improved petrologic and geochemical models for the evolution of continental crust. Geothermo-barometric studies of granulite terrains suggest temperatures in the range of $700^{\circ}$ to $900^{\circ} \mathrm{C}$ and pressures of 5 to $10 \mathrm{kbar}$, implying anomalously high temperatures and deep burial during granulite facies metamorphism. These results clearly indicate some considerable thermal perturbations in the deep crust that are different and locally steeper than the normal ambient continental geothermal gradient (e.g. Ganguly et al 1995).

The Adirondack Mountains of New York have been an important area for the study of massiftype anorthosites and associated granulites for formulating and testing many of the ideas of petrologic, thermal-barometric, geochronological, isotopic, and geochemical aspects of granulite facies metamorphism. It is generally believed

Keywords. Granulites; geochronology; petrogenesis; Adirondacks; zircon age. 


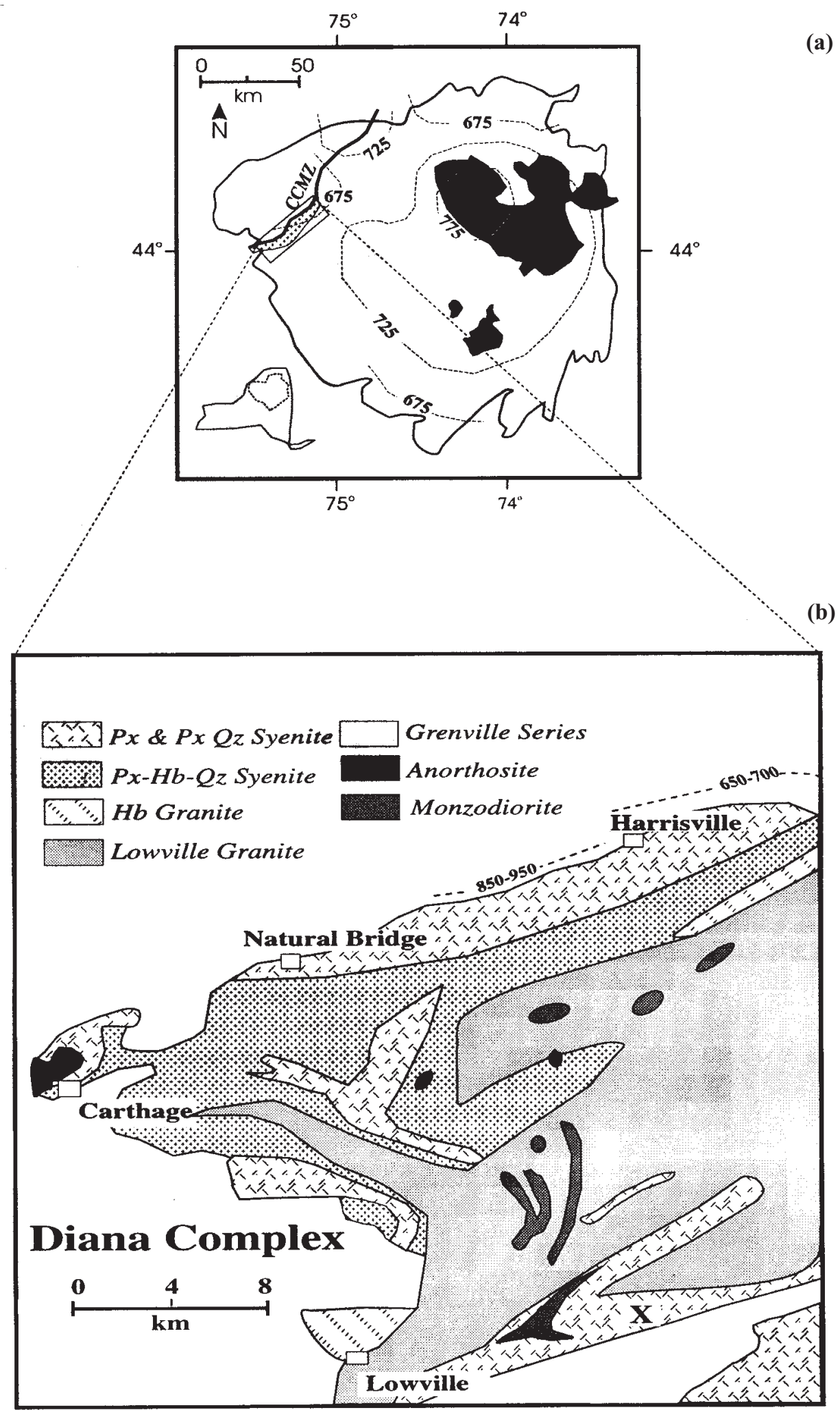

Figure 1. (a). Outline of the Adirondack Mountains, New York, showing the anorthosite massifs (in black) in the central highlands and the Carthage-Colton Mylonite Zone (CCMZ) to the northwest. The CCMZ demarcates the upper amphibolite-facies rocks to the northwest from the higher granulite-grade rocks to the southeast. The location of the Diana Complex is shown in the rectangular box. The contours represent the temperatures of regional metamorphism in degree Celsius, determined from mineralogic thermometers as summarized by Valley et al (1994). (b). Simplified lithologic map of the Diana Complex, after Buddington (1939), showing the location of the hornblende-pyroxene syenite (cross) from which the different zircon fractions were separated and analyzed in the present study for U-Pb age determination. The broken lines above Harrisville represent isotherms in degree celsius for contact metamorphism of the adjacent metasediments, as discovered by Powers and Bohlen (1985). 
that the north-northeast trending structure within the Adirondack dome (figure 1a) exposes a section of the middle Proterozoic crust composed of upper amphibolite to granulite facies rocks. Granitic, charnockitic and anorthositic gneisses of the Adirondack highlands along with some intervening metasediments have also been considered as a plausible section of the deep continental crust. High-grade regional metamorphism associated with the Grenville event (ca $1100 \mathrm{Ma}$ ) has pervasively affected the entire Adirondack region, and the progressive transition from upper amphibolite to granulite-facies metamorphism across the major paragneisses surrounding the anorthosite and other orthogneisses has been well-documented in the northwest Adirondacks (e.g., Edwards and Essene 1988). Extensive geothermo-barometric studies of Adirondack metamorphism (e.g., Bohlen et al 1985; Newton 1985) have documented strong correspondence between the highest temperatures and pressures and the outline of the main anorthosite massif in the Adirondack highlands (figure 1a). These results are summarized by several workers (e.g. Newton 1985; Bohlen et al 1985) based on the investigations of Buddington (1963); Bohlen and Essene (1977); Johnson and Essene (1982); Newton (1983) and others. These pressure-temperature estimates, which form a "bull's-eye" pattern centered around the anorthosite massif (figure 1a), may have important implications concerning the timing of anorthosite intrusion, metamorphism, and the uplift of the Adirondack highlands.

During the past four decades, geochronological evidence for Adirondack metamorphism and anorthosite intrusion has been interpreted with broadly different results. The first definitive U$\mathrm{Pb}$ isotopic study of zircons by Silver (1969) indicated no evidence of age of intrusion significantly older than $1115 \mathrm{Ma}$ among the orthogneisses of the Adirondack highlands. In addition, Silver's data demonstrated an overall duration of $80 \pm 25 \mathrm{Ma}$ for the post-anorthosite episode of metamorphism. An internal mineral and whole-rock $\mathrm{Sm}-\mathrm{Nd}$ isotopic study for garnetiferous anorthosites of the Snowy Mountain massif in the central Adirondacks gave the time of formation of the garnets and possibly of the minimum age of crystallization of the anorthosites at $1100 \mathrm{Ma}$ (Basu and Pettingill 1983), consistent with Silver's interpretation of the $\mathrm{U}-\mathrm{Pb}$ data in zircons. Although these studies, among others, indicated the synchroneity of anorthosite emplacement, and the continuity and duration of metamorphism following plutonism, many Adirondack workers during the last two decades (e.g., Ashwal and Wooden 1983, Valley 1985; McLelland and Isachsen 1986; and others) accepted a broad window of 400 Ma between the timing of magmatic and metamorphic events in the Adirondacks. This view was primarily based on the Sm-Nd systematics results of Ashwal and Wooden (1983) that yielded isochron ages between 1288 and 919 Ma for anorthosite emplacement and the following metamorphic episodes. In the light of new U-Pb data (Chiarenzelli et al 1987; McLelland et al 1988; McLelland and Chiarenzelli 1989, 1990; Mezger et al 1991) of meta-igneous and metasedimentary rocks of the Adirondack region, Silver's (1969) broad interpretations have now been vindicated and it appears likely that Ashwal and Wooden's (1983) results reflected disturbed SmNd systematics (McLelland et al 1988). However, controversies still exist on whether the rocks adjacent to the anorthosites experienced polymetamorphism (e.g., Valley et al 1990) or, that the central anorthosite massifs intruded contemporaneously with the anorthosite-mangerite-charnockitegranite (AMCG) suite (Emslie and Hunt 1989; McLelland and Chiarenzelli 1990; Chiarenzelli and McLelland 1991), followed by granulite-grade metamorphism.

In this paper, we have attempted high-precision $\mathrm{U}-\mathrm{Pb}$ dating of single and multiple grains of zircons from the Diana Syenite Complex of the northwest Adirondacks. Our purpose is to address some of the above questions of precise age relationships between timing of intrusion and metamorphism. We provide detailed petrographic information on the zircons analyzed (table 1) and, in conjunction with the U-Pb isotopic analyses of the zircons, we demonstrate that many of the zircon fractions from the same hand-specimen of a syenite contain either primary magmatic grains with metamorphic overgrowths, or older xenocrystic core material rimmed by magmatic portions, as well as some rare purely "magmatic" grains. It is the analyses of the rare magmatic grains that produced nearly concordant ages, consistent with the expected field, petrologic, geothermo-barometric, and other geochronological studies of Adirondack granulite lithology.

\section{Diana Syenite Gneiss Complex of northwest Adirondacks}

The Diana Quartz Syenite Gneiss Complex is composed of a variably metamorphosed rock series ranging from augite-hypersthene syenite through augite syenite, augite-hornblende syenite, hornblende-quartz syenite, granosyenite and granite (Buddington 1939, 1963). Buddington (1939) and Hargraves (1969) interpreted the Diana Complex as a metamorphosed, differentiated quartz-syenite igneous intrusive exposed along the Carthage-Colton Mylonite Zone (CCMZ), speculating that the CCMZ represented an overthrust fault zone marked by mylonitization with the 


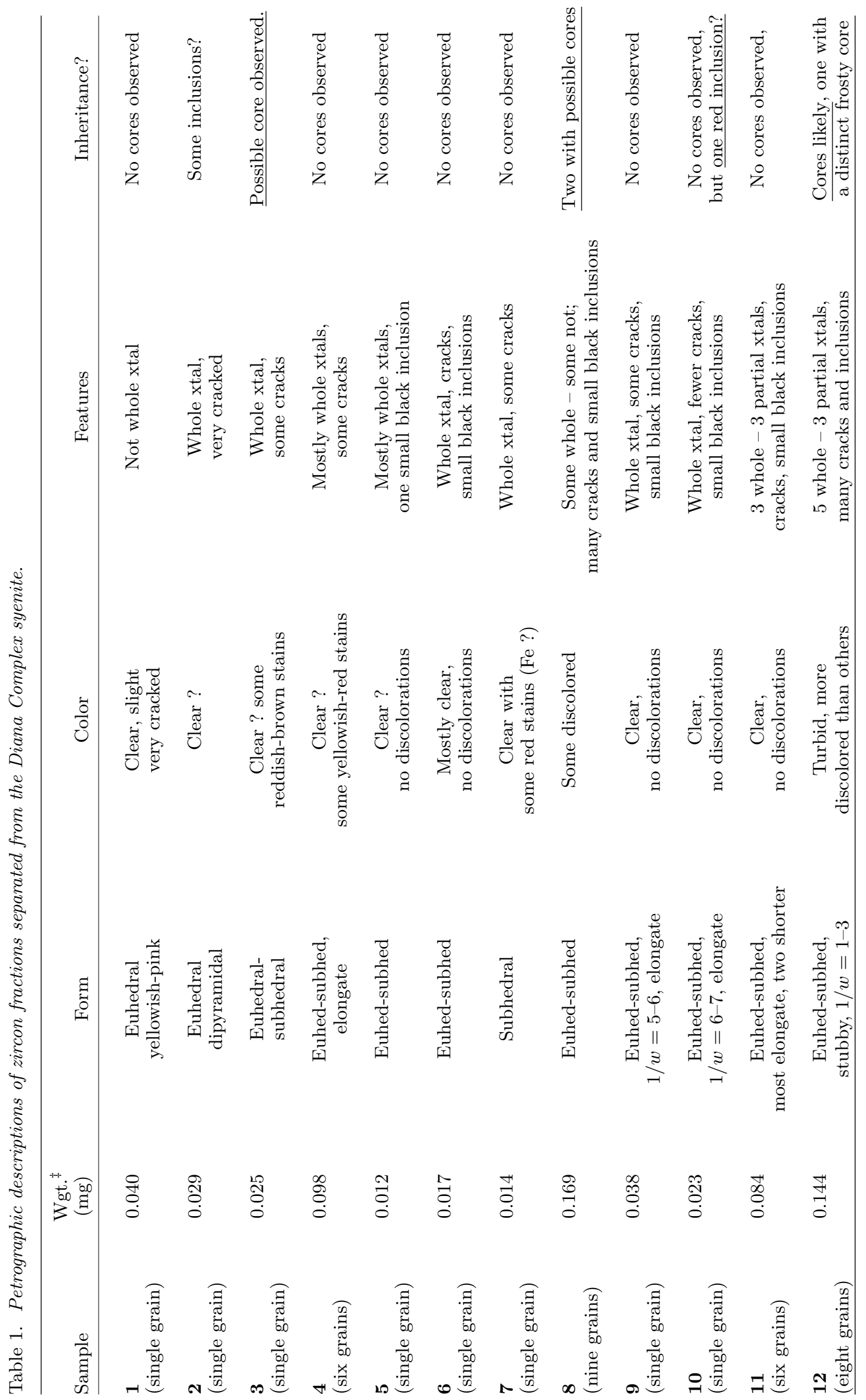


Grenville belt in the northwest thrust over the main Adirondack massif to the southeast. Figure 1(a) shows the location of the CCMZ in the northwest Adirondacks, including the extent of the Diana Complex within it to the southwest, and its relationship with the major anorthosite domes in the central highlands. The concentric patterns of isothermal contours in figure 1(a) are those of metamorphic temperatures estimated from various mineralogical thermometers as summarized by Bohlen et al (1985). The CCMZ is an important petro-tectonic marker in the sense that it separates the upper amphibolite facies rocks to the northwest from the granulite-facies rocks in the eastern highlands.

Figure $1(b)$ is a simplified geological map of the Diana Complex after Buddington (1939), who considered the various lithologies as belonging to a closely folded, isoclinally overturned, gravitystratified plutonic sheet of rocks with an underlying chilled-facies of pyroxene syenite. The Diana syenites are quite similar in mineralogy to the hypersthene granulites of the Adirondack highlands. The Diana pyroxene syenites may belong to the charnockitic or mangeritic rock series surrounding the main anorthosite massifs in the highlands as suggested by DeWaard (1969), although the average Diana syenite contains only 0.7 per cent hypersthene in the mode (Buddington 1939). It is interesting that Buddington's (1939) petrologic description of the various lithologic units of the Diana Complex (figure 1b) can be matched precisely by the volumetrically dominant, bimodal suite of meta-igneous rocks of the Adirondack highlands, including anorthosite, mangerite, charnockite, and granite (the AMCG suite).

A precise information on the primary crystallization age of the Diana Igneous Complex would be highly desirable for at least two reasons. First, the Diana Complex is lithologically similar and possibly genetically related to other mangeritic and charnockitic complexes in direct contact with the anorthosites of the central Adirondacks (Buddington 1939; DeWaard 1969; Wiener 1983). Thus, the age of primary crystallization of the Diana Syenites would correlate with that of the granulitic metaigneous rocks in the central Adirondacks. Second, the discovery by Powers and Bohlen (1985) of a contact metamorphic aureole, decreasing from $850-950^{\circ} \mathrm{C}$ along the Diana-metasediment contact to $650-700^{\circ} \mathrm{C}$ within $2-3 \mathrm{~km}$ from the contact (figure 1b), has important implications for Adirondack metamorphism. Powers and Bohlen (1985) interpreted their observation as a "preserved synregional metamorphic contact aureole," because it is highly unlikely for the observed contact aureole to have survived the regional granulite-grade metamorphism advancing later from the central Adiron- dacks. This interpretation is consistent with the increased degree of partial melting of the metasediments towards the Diana syenite contact (Powers and Bohlen 1985). The above considerations prompted us to undertake the current study to determine the age of crystallization of the Diana Complex, and to infer the relative timing of granulite metamorphism in the Adirondacks, and to explore a possible cogenetic relationship among the various meta-igneous lithologies.

\section{Analytical methods}

Zircons from a sample of syenite within the Diana Complex (marked with a cross in figure 1b) were separated using conventional methods of crushing, sieving, density and magnetic separations. This rock is a foliated medium-grained, equigranular, alkali-hornblende-pyroxene syenite, collected from a road-cut approximately $1 \mathrm{~km}$ east of Crystal Dale. Detailed petrographic studies of the entire unbiased zircon population revealed that most grains contained at least two phases of zircon growth, either primary magmatic portions enclosed by variable thicknesses of metamorphic overgrowths or magmatic portions enclosing presumably older xenocrystic zircon cores (figure 2a). The magmatic portions are characterized by typical dipyramidal prismatic zoning and numerous small black inclusions that make them quite distinct from adjacent overgrowths or cores when observed through plane-polarized or crossed nicols (figure 2b) or in back-scattered electron micrographs. A significant percentage of grains exhibited all three components. Careful handpicking of the "best" magmatic euhedral grains, devoid of visible overgrowth or core materials with a larger length to width ratios, was attempted in this study in order to minimize two-component mixing in our analyses. Individual zircon grains, both whole and fragmented, as well as multi-grain fractions were hand-picked from a least-magnetic, heavy concentrate, primarily based on their clarity, form, and lack of inclusions as well as observable overgrowths or cores. A list of petrographic observations made under a reflected-light, binocular microscope prior to dissolution is given in table 1 . In general, only grains (whole or fragmented) that were relatively colorless, inclusion-free, core-free with good dipyramidal prismatic form (euhedral to subhedral), length to width $(1 / \mathrm{w})$ ratios greater than 3 (except fraction 12), and with some indication of magmatic growth zones were selected. Unfortunately, most of the magmatic-looking grains also had numerous small black inclusions that were not always discernible from xenocrystic cores. Several of the fractions contained possible xenocrys- 

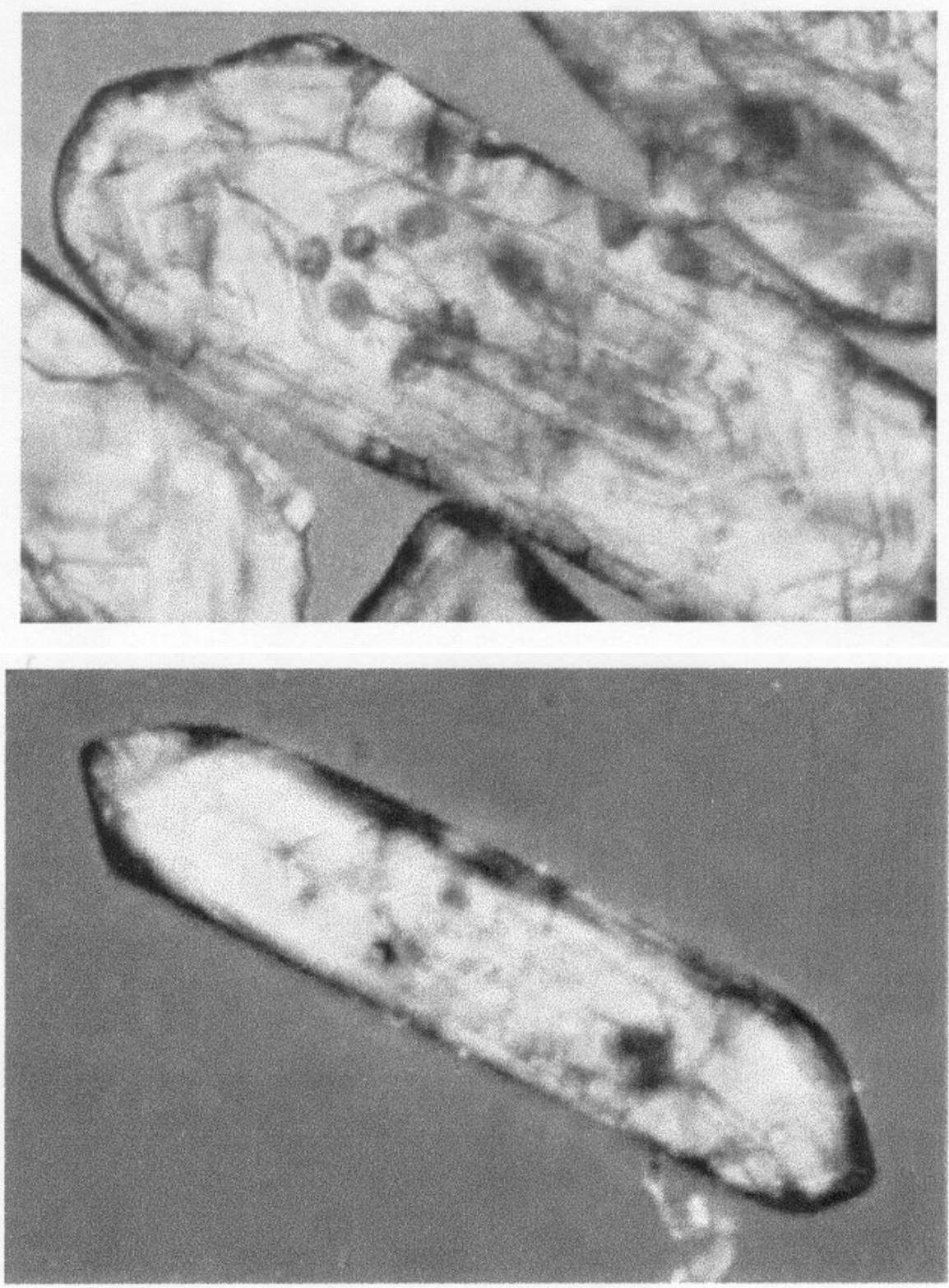

(b)

Figure 2. (a). Polarized light photomicrograph in crossed nicols of a zircon population from the syenite, showing multiple overgrowths, heterogeneous cores, and numerous other mineral inclusions. Analyses of these zircons show them to be widely discordant with variable amounts of inherited $\mathrm{Pb}$ components in the $\mathrm{U}-\mathrm{Pb}$ isotope systematics diagram (figure 3 ). Polarizing light microsopic observations of these zircons revealed the numerous inclusions as apatite and zircons. Notice also the stubby habits of the zircons. Long dimension of photomicrograph is $0.75 \mathrm{~mm}$. (b). Polarized light micrograph of a single, magmatically zoned, euhedral zircon in crossed nicols from the same syenite in which the more common zircons look like those in figure 2(a). Notice smooth, long, slender, euhedral crystal (part of the grain is under the epoxy and not visible in this view) without inclusions and metamorphic cores. We consider this type of grain as "magmatic" and they give near-concordant $\mathrm{U}-\mathrm{Pb}$ ages. Our conclusions of the primary crystallization age of the Diana Complex is based on the analyses of several grains of zircons similar to this crystal. Long dimension of photograph is $0.40 \mathrm{~mm}$.

tic core material, including fractions 3,8 , and 12. Also, nearly every grain was highly fractured. Whether this attribute was caused during sample preparation or by some natural process is uncertain.

The analytical methods for the dissolution of the zircons and the extraction of $\mathrm{U}$ and $\mathrm{Pb}$ are the same as those given in Premo and others (1990), which also includes the multi-sample, vapor-dissolution technique of Krogh (1978). Prior to dissolution, the zircon grains were weighed into PFA Teflon vials, cleaned in distilled $7 \mathrm{~N} \mathrm{HNO}_{3}$, and spiked with a ${ }^{205} \mathrm{~Pb}_{-}{ }^{233} \mathrm{U}_{-}{ }^{236} \mathrm{U}$ dilute tracer solution. Dissolution was achieved in distilled concentrated $\mathrm{HF}+\mathrm{HNO}_{3}$ in a large (6.5-cm-diameter) Parrtype TFE Teflon dissolution vessel in $210^{\circ} \mathrm{C}$ for about 5 days. $\mathrm{U}$ and $\mathrm{Pb}$ from individual grains were extracted using anion exchange resins, $\mathrm{Pb}$ in an $\mathrm{HBr}$ medium and $\mathrm{U}$ in a $\mathrm{HNO}_{3}$ medium. Total analytical blanks (laboratory contamination) measured 25 to $70 \mathrm{pg}$ for $\mathrm{Pb}$ and 1 to $3 \mathrm{pg}$ for $\mathrm{U}$ (see table 2). 


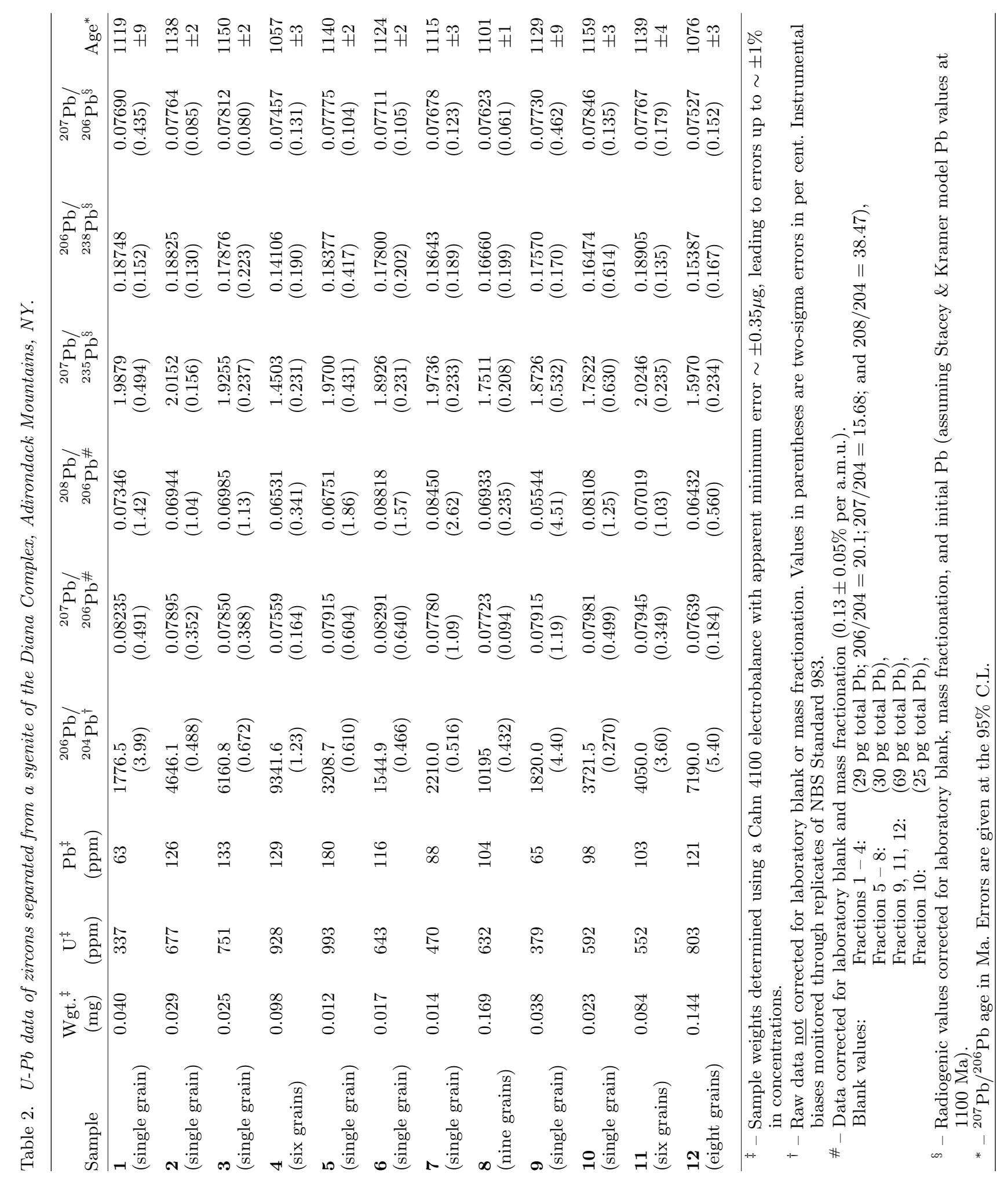


$\mathrm{Pb}$ was loaded onto a single Re filament using the silica-gel-phosphoric acid method, and isotopic ratios were measured using either an NBS-type tandem (two-stage) mass spectrometer equipped with an ion pulse counter at the end of the second stage or VG Isomass $54 \mathrm{E}$. Pb isotopic ratios were corrected for mass fractionation and laboratory blank $\mathrm{Pb}$ (values given in the footnotes of table 2); and for initial common $\mathrm{Pb}$ using values of Stacey and Kramers (1975) for the appropriate age of the sample at ${ }^{238} \mathrm{U} /{ }^{204} \mathrm{~Pb}=9.74$. Uncertainties in isotopic ratio measurements are given in table 2 , and are reported at the two-sigma level. Ages were calculated using decay constants from Steiger and Jäger (1977). Concordia intercept ages and errors were determined using the algorithms of Ludwig $(1980,1987)$, which use the regression approach of York (1969); uncertainties on the ages are reported at the $95 \%$ confidence level.

\section{Results}

The U-Pb isotopic data from the twelve analyses, including the 8 single-grain are given in table 2 and shown on a conventional concordia diagram (figure 3). U concentrations range between 340 and $1000 \mathrm{ppm}$, not unlike other syenitic zircons. There is a rough correlation between $U$ content and concordancy. The higher the $\mathrm{U}$ content, the greater is the degree of discordance, although there are exceptions. The analyses were relatively clean, uncorrected ${ }^{206} \mathrm{~Pb} /{ }^{204} \mathrm{~Pb}$ values ranged between 1500 and 10,200 , so that corrections for common $\mathrm{Pb}$ were very slight.

The analyses are neither concordant nor collinear on the Concordia diagram (figure 3 ). The spread in ${ }^{207} \mathrm{~Pb} /{ }^{206} \mathrm{~Pb}$ ages (table 2) was from $1057 \mathrm{Ma}$ (fraction \#4) to $1159 \mathrm{Ma}$ (fraction \#10), although for the most concordant analyses, the ages ranged from 1115 to $1150 \mathrm{Ma}$. These differences are outside the ${ }^{207} \mathrm{~Pb} /{ }^{206} \mathrm{~Pb}$ age error limits (table 2), indicating that some of the fractions contain at least two components of zircon growth of different ages. At the beginning of our selections of zircon grains, we purposefully picked the "best" grain first. This grain, in our opinion, was fraction \# 1, and was the largest, euhedral, and most clear zircon in the entire population. As it turned out, analysis \# 1 is also the most concordant, yielding $\mathrm{a}^{207} \mathrm{~Pb} /{ }^{206} \mathrm{~Pb}$ age of $1119 \pm 9 \mathrm{Ma}$ (figure 3 ).

Whereas other single grains were selected that were "next best", none except analysis \# 7, turned out to be so concordant. Analysis \# 7 also had a young ${ }^{207} \mathrm{~Pb} /{ }^{206} \mathrm{~Pb}$ age of $1115 \pm 3 \mathrm{Ma}$. Because of the close proximity and relatively large errors on these two analyses, a chord between them does not yield a useful age. Analyses \# 4 and \# 12 are both batch fractions of six and eight grains, respectively, that were not observed to be of the very best quality, and \# 12 possibly included a grain containing xenocrystic core material that happens to lie very near this chord. A regression of analyses \#1, $\# 7$, \#4, and \#12 yields an upper-intercept age of $1118 \pm 2.8 \mathrm{Ma}$ (figure 3 ) that we presently interpret as the "best estimate" towards the true age of the syenite from the Diana Complex. The remaining analyses, therefore, are interpreted as containing variable amounts of inherited older $\mathrm{Pb}$ due to incorporation of xenocrystic zircon cores within the primary magmatic portion of the grain $(\mathrm{s}) . \mathrm{Pb}$ isotopic compositions of older xenocrystic zircon have higher ${ }^{207} \mathrm{~Pb} /{ }^{206} \mathrm{~Pb}$ values, so that even some small fragment of this older component will cause the analyses to shift slightly to the right of the 1118-Ma chord (figure 3). Some of these fractions were observed to have xenocrystic cores, but for the most part, they were not obviously visible during handpicking. This situation is not too surprising after viewing the small size and similar color of these cores to other normal black inclusions. Our observations, however, identify the cores by their central nature within the magmatic portion of some grain(s). Growth zones tend to emanate from the cores, which is a likely situation since the xenocrystic cores are thought to act as seeds in order to nucleate normal zircon growth within a magma reservoir. Other chords can be constructed through the analyses, but only a few yield lower intercept ages that are reasonably consistent with probable Appalachian uplift ages between $\sim 200$ and 400 Ma. Thus our "best estimate" chord with a lower-intercept age of $251 \pm 13 \mathrm{Ma}$ (figure 3) may indeed support this regression as a "best estimate." Individual analytical points are considered mixtures of older inherited $\mathrm{Pb}$ and primary magmatic $\mathrm{Pb}$ (and possibly younger overgrown $\mathrm{Pb}$ as well) which yield a false crystallization age of $\sim 1145 \mathrm{Ma}$.

\section{Discussion}

It is our opinion that the "best estimate" for the crystallization age of the syenite from the Diana Complex is $1118 \pm 2.8 \mathrm{Ma}$ based on the observations and reasoning given above. By analyzing only the "best" single magmatic grains we were able to decipher this age. This age is in conflict with a $\mathrm{U}-\mathrm{Pb}$ zircon age of $1155 \pm 4 \mathrm{Ma}$ from a syenite reported by Grant et al (1986); however, the details of this zircon age results were never published, and reported only in an abstract (the isotopic data were not published). It may have been determined using relatively large zircon populations (mg-size) to measure the radiogenic $\mathrm{Pb}$ isotopic compositions. As we pointed out above, many of the zircon 


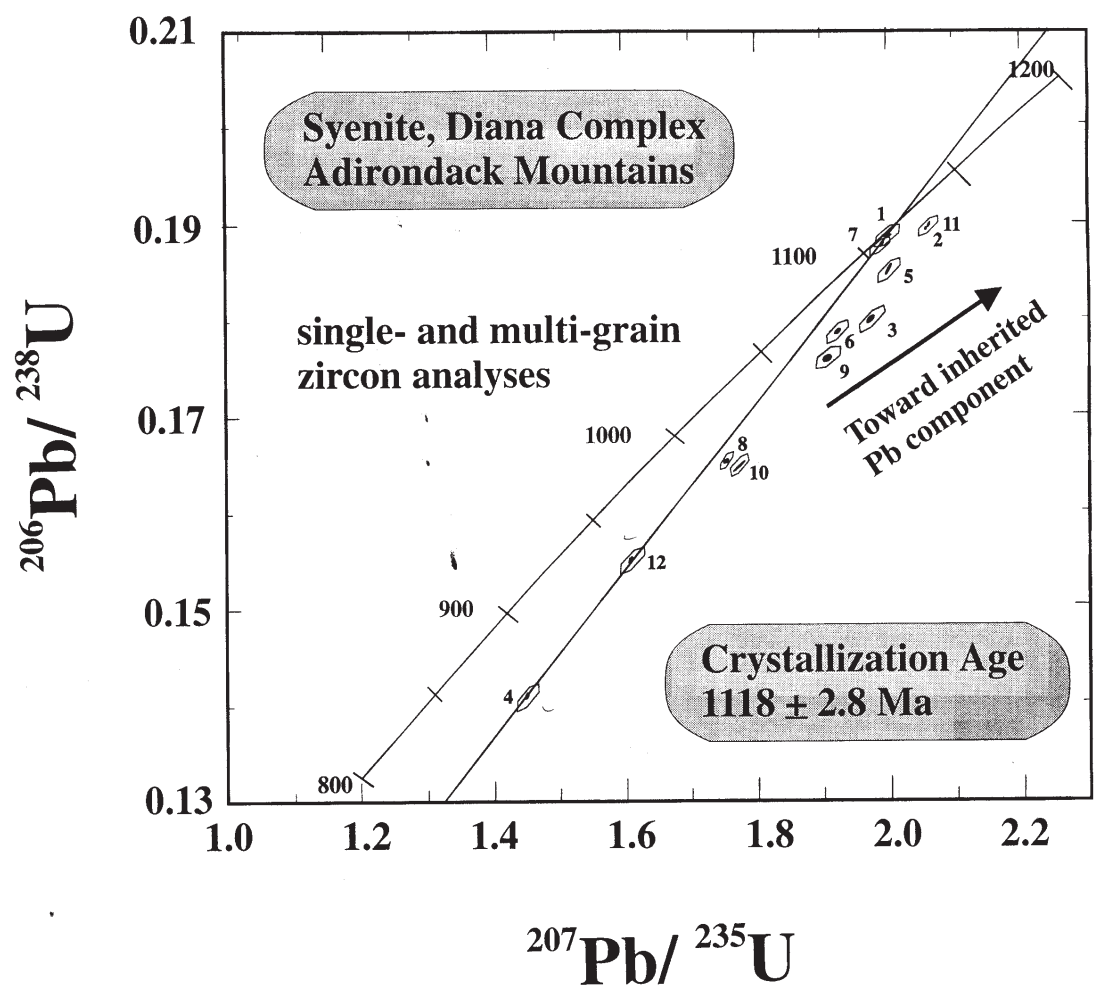

Figure 3. U-Pb concordia diagram plot of the twelve analyses in table 2 of the single and multi-grains of zircons from the syenite of the Diana Complex. The age of $1118 \mathrm{Ma}$ is obtained by the regression of two single-grain (\#1 and \#7) and two multi-grain (\#4 and \#12) analyses. See table 1 for petrographic descriptions of the zircons analyzed in this study.

fractions may contain mixtures of two or more zircon components (e.g. overgrowths, magmatic portions, and older xenocrystic cores) that can lead to false (perhaps older) ages. We believe that this is the case here. A reaffirmation of the zircon age from Grant et al (1986) was also made by U-Pb mineral age of metamorphic rocks from the contact zone of the Diana Complex (Mezger et al 1991), and an age of $1153 \pm 3 \mathrm{Ma}$ was reported for garnets in the syn-regional metamorphic contact aureole of the Diana syenite. Our preferred age of crystallization of the Diana Complex at $1118 \mathrm{Ma}$ is some 35 Ma younger than this contact-metamorphic $\mathrm{U}-\mathrm{Pb}$ garnet age of Mezger et al (1991). This discrepancy could be due to the low concentration of $U$ $(1.89 \mathrm{ppm})$ in the garnets and the uncertainty in our knowledge of submicroscopic scale inclusions of older $\mathrm{U}-\mathrm{Pb}$ bearing minerals in the garnets. The strong similarity between the U-Pb age of zircon by Grant et al (1986) and the contact-metamorphic U$\mathrm{Pb}$ age of garnet growth by Mezger et al (1991) is indeed puzzling. This is because Grant et al's zircon age is very likely a magmatic crystallization age and, therefore, should be older than the intrusioninduced, contact-metamorphosed garnets, dated by Mezger et al (1991). Furthermore, acceptance of the ca $1155 \mathrm{Ma}$ for Diana requires that the U-Pb closure temperatures for zircons and garnets are the same, and that the conductive-convective heat- ing of the Diana country rocks were almost instantaneous with the intrusion. Both these requirements cannot be accepted because garnet closes at lower temperature with respect to $\mathrm{U}-\mathrm{Pb}$ diffusion than zircon, and the relatively large $2-3 \mathrm{~km}$ distance between the dated garnet and the intrusive contact. Therefore, we prefer our $1118 \mathrm{Ma}$ age for Diana.

It is noteworthy that the $1118 \mathrm{Ma}$ age for the Diana Complex, as indicated by this study, is consistent with Silver's (1969) conclusion regarding the age of intrusion of the anorthosite-charnockite suite, and the more recent assertion by McLelland and Chiarenzelli (1990) on the basis of field evidence and $\mathrm{U}-\mathrm{Pb}$ dating that the main anorthosite body of the Adirondacks (Marcy Massif) intruded sometime during 1113 to 1138 Ma. Acceptance of the $1118 \mathrm{Ma}$ age of intrusion for the Diana Syenites, as proposed here, independently supports the general conjecture prevalent among Grenville geologists, Adirondacks in particular, of the contemporaneity of the anorthosite-mangeritecharnockite suite of rocks (e.g., McLelland et al 1988; Emslie and Hunt 1989). The synchroneity of the Diana Complex with the anorthosite massifs of the Adirondack highlands has important implications for the petrogenesis of the meta-igneous suite, and the following granulite-grade metamorphism. The results of this study and those of the Sm-Nd 
systematics of the major meta-igneous rocks of the Adirondacks, including the anorthosites, gabbros, mangerites, charnockites, and granites (Sharma and Basu 2001, in preparation), indicate consanguineous relationship among these rock-types, possibly accompanying assimilation and fractional crystallization processes in a large body of mantlederived mafic magma emplaced around $1120 \mathrm{Ma}$ in the lower crust. The regional granulite to upper amphibolite grade metamorphism of the Adirondacks was also synchronous with this igneous activity, as indicated by the contact metamorphic aureole around the Diana Complex (Powers and Bohlen 1985) and began as early as $1118 \mathrm{Ma}$, and continued through $1050 \mathrm{Ma}$ (Basu and Pettingill 1983; McLelland et al 1988; Basu et al 1989). The regional granulite metamorphism cannot be younger than the age of intrusion of the Diana at $1118 \mathrm{Ma}$ because the younger high-grade regional metamorphism would have completely erased the contact metamorphic aureole adjacent to Diana. The only viable option is to accept the synchroneity of granulite metamorphism with the igneous activity in the Adirondacks because, as we have discussed above, there is no credible evidence for the granulite metamorphism to be older than the intrusion.

Previous zircon age determinations for many meta-igneous rocks from the Adirondack Mountains as well as surrounding orogenic belts have utilized relatively large zircon populations (mg-size) to measure the radiogenic $\mathrm{Pb}$ isotopic compositions (Grant et al 1986; McLelland et al 1988; McLelland and Chiarenzelli 1989; Chiarenzelli and McLelland 1991). We have demonstrated here that it is very possible that many of these zircon fractions may contain mixtures of two or more zircon components (e.g. overgrowths, magmatic portions, and older xenocrystic cores) that can lead to older ages. If the largest, euhedral and most clear grain of the zircon population is also most concordant, reliable age information of the primary crystallization of the meta-igneous rocks can be obtained.

\section{Conclusions}

We have provided new U-Pb isotopic data in zircons from a syenite of the Diana Complex, northwest Adirondacks. The crystallization age of the Diana Complex, inferred from the "best" magmatic grains of zircons, is nearly concordant at $1118 \mathrm{Ma} \pm 2.8 \mathrm{Ma}$. This age, $35 \mathrm{Ma}$ younger than previously believed, is approximately synchronous with the age of intrusion of the main anorthosite massif in the central highlands, suggesting a cogenetic relationship among the vari- ous meta-igneous rocks. Because the Diana Complex is partially enclosed by a high temperature contact-metamorphic aureole, the $1118 \mathrm{Ma}$ age is also the time of initiation of Adirondack regional metamorphism which continued through $1100 \mathrm{Ma}$ until 1050 Ma. These geochronological results, consistent with an earlier study by Silver (1969), imply that the anomalously high temperatures for granulite metamorphism in the Adirondack Mountains were caused by the syn-metamorphic intrusions of the anorthosite-mangerite-granite suite of rocks, without multiple periods of heating and cooling, and burial and uplift.

\section{Acknowledgements}

This research was partially supported by the National Science Foundation and by the Branch of Isotope Geology, U.S. Geological Survey, Denver. We are grateful to the late M. Tatsumoto for his encouragement and technical support during the course of this study. Discussions with Mukul Sharma at various stages of this work were also helpful. This manuscript benefited from constructive reviews and comments by J Aleinikoff, J Ganguly, Y Isachsen, and R E Zartman.

\section{References}

Ashwal L D and Wooden J L $1983 \mathrm{Sr}$ and Nd isotope geochronology, geologic history and origin of the Adirondack Anorthosite; Geochimica Cosmochimica Acta 47 1875-1885

Basu A R and Pettingill H S 1983 Origin and age of Adirondack anorthosites re-evaluated with Nd-isotopes; Geology 11 514-518

Basu A R, Faggart B E and Sharma M 1989 Implications of Nd-isotopic study of Proterozoic garnet amphibolites and wollastonite skarns from the Adirondack Mountains, New York: Proc. 28th Internat. Geol. Congr. Washington, D.C 1 95-96

Bohlen S R and Essene E J 1977 Feldspar and oxide thermometry of granulites in the Adirondack Highlands; Contributions to Mineralogy and Petrology 26 971-992

Bohlen S R, Valley J W and Essene E J 1985 Metamorphism in the Adirondacks, I. Petrology, pressure and temperature; J. Petrology 26 971-992

Buddington A F 1939 Adirondack igneous rocks and their metamorphism; Geological Society of America Memoir $\mathbf{7}$ $354 \mathrm{pp}$.

Buddington A F 1963 Isograds and the role of 20 in metamorphic facies of orthogneisses of the northwest Adirondacks area, New York; Geological Society of America Bulletin 74 1155-1182

Chiarenzelli J R, Bickford M, McLelland J, Isachsen Y and Whitney P 1987 Early igneous history of the Adirondacks as revealed by the U-Pb zircon analysis; Geological Society of America Abstract $\mathbf{1 9} 619$

Chiarenzelli J R and McLelland J M 1991 Age and regional relationships of granitoid rocks of the Adirondack Highlands; J. Geology 99 571-590 
DeWaard D 1969 Facies series and P-T conditions of metamorphism in the Adirondack Mountains; Proc. Koninkl. Ned. Akad. Wetensch B72 124-131

Edwards R L and Essene E J 1988 Pressure, temperature, and $\mathrm{C}-\mathrm{O}-\mathrm{H}$ fluid fugacities across the amphibolitegranulite transition, N.W. Adirondack Mtn., NY; J. Petrology 29 39-72

Emslie R F and Hunt P A 1989 Ages and petrogenetic significance of igneous mangeritecharnockite suites associated with massif anorthosites, Grenville Province; J. Geology 98 213-231

Ganguly J, Singh R N, Ramana D V 1995 Thermal perturbation during charnockitization and granulite facies metamorphism in southern India; J. Metamorphic Geology 13 419-430

Grant N K, Lepak I, Maher T M, Hudson M R and Carl J D 1986, Geochronological framework for the grenville rocks of the Adirondack Mountains (abstract); Geological Society America Abstracts with Programs 18620

Hargraves R B 1969 A contribution to the geology of the Diana Syenite gneiss complex. In: Origin of Anorthosite and Related Rocks: New York Museum Science Service Memoir (ed) I W Isachsen, 18 343-356

Johnson C A and Essene E J 1982 The formation of garnet in olivine-bearing metagabbro from the Adirondacks; Contributions to Mineralogy and Petrology 81 240-251

Krogh T E 1978 Vapor transfer for the dissolution of zircons in a multi-sample capsule at high-pressure. In: Short papers of the Fourth International Conference on geochronology, cosmochronology, isotope geology; U.S. Geological Survey Open-File Report (ed) R E Zartman, 78-701 233-234

Ludwig K R 1980 Calculation of uncertainties of U-Pb data; Earth and Planetary Science Letters 46 212-220

Ludwig K R 1987 ISOPLOT200: A Plotting and regression program for isotope geochemists, for use with HP Series 200 Computers; U.S. Geological Survey Open-File Report 85-513 47 p.

McLelland J M and Chiarenzelli 11989 Age of xenolithbearing olivine metagabbro, eastern Adirondacks, New York; J. Geology 97 373-376

McLelland J M and Chiarenzelli 11990 Isotopic constraints on emplacement age of anorthositic rocks of the Marcy Massif, Adirondack Mountains, New York; J. Geology 98 $19-41$

McLelland J M, Chiarenzelli J R, Whitney P and Isachsen Y $1988 \mathrm{U}-\mathrm{Pb}$ zircon geochronology of the Adirondack Mountains and implications of their geologic evolution; Geology 16 920-924

McLelland J M and Isachsen Y 1986 Geological synthesis of the Adirondack Mts. and their tectonic setting within the SW Grenville Province. In: The Grenville Province: New Perspectives; Geological Association Canadian Special Paper (eds) J Moore, A Davidson, and A Baer, 31 75-94
Mezger K, Rawnsley C M, Bohlen S R and Hanson G N 1991 $\mathrm{U}-\mathrm{Pb}$ garnet, sphene, monazite, and rutile ages: Implications of the duration of high-grade metamorphism and cooling histories, Adirondack Mtns., New York; J. Geology 99 415-428

Newton R C 1983 Geobarometry of high grade metamorphic rocks; Am. J. Sci. 283-A 1-28

Newton R C 1985 Temperature, pressure and metamorphic fluid regimes in the amphibolite facies to granulite facies transition zones. In: The deep proterozoic crust in the north Atlantic provinces, (eds) A C Tobi and J L R Touret, (D. Reidel Publishing Company) p. 75-104

Powers R E and Bohlen S R 1985 The role of synmetamorphic igneous rocks in the metamorphism and partial melting of metasediments, N.W. Adirondacks; Contributions to Mineralogy and Petrology 90 401-409

Premo W R, Helz R T, Zientek M L and Langston R B $1990 \mathrm{U}-\mathrm{Pb}$ and $\mathrm{Sm}-\mathrm{Nd}$ ages for the Stillwater Complex and its associated sills and dikes, Beartooth Mountains, Montana: Identification of a parent magma? Geology 18 1065-1068

Sharma M and Basu A R 2001 Crustal accretion and mantle-differentiation in the Proterozoic: Sm$\mathrm{Nd}$ isotopic evidence from the Adirondack Mountains, New York; Contributions to Mineralogy and Petrology (in preparation)

Silver L 1969 A geochronologic investigation of the anorthosite complex, Adirondack Mts., New York. In: Origin of Anorthosites and Related Rocks; New York State Museum Science Service Memoir (ed) Y Isachsen, $18233-252$

Stacey J S and Kramers J D 1975 Approximation of terrestrial lead isotope evolution by a two stage model; Earth Planet. Sci. Lett. 26 207-221

Steiger R H and Jäger E 1977 Subcommission on Geochronology: convention on the use of decay constants in geo- and cosmochronology; Earth Planet. Sci. Lett. 36 359-362

Valley J W 1985 Polymetamorphism in the Adirondacks: Wollastonite at contacts of shallowly intruded anorthosite. In: The Deep Proterozoic Crust in the North Atlantic Provinces (eds) C A Tobai and J L R Touret, (Dordrecht: Reidel) p. 217-236

Valley J W, Bohlen S R, Essene E J and Lamb W 1990 Metamorphism in the Adirondacks: II. The Role of Fluids; J. Petrology 31 555-596

Valley J W, Chiarenzelli J R and McLelland J M 1994 Oxygen isotope geochemistry of zircon; Earth Planet. Sci. Lett. 126 187-206

Wiener R W 1983 Adirondack Highlands-Northwest Lowlands 'boundary': A multiply folded intrusive contact with fold-associated mylonitization; Bulletin Geological Society America 94 1081-1108

York D 1969 Least-squares fitting of a straight line with correlated errors; Earth Planet. Sci. Lett. 5 320-324 